\title{
ANALISIS RESPON GERAK FLOATING CRANE BARGE UNTUK DECOMMISSIONING STRUKTUR LEPAS PANTAI
}

\section{Motion Response Analysis of a Floating Crane Barge for the Decommissioning of Offshore Structures}

\author{
Nurman Firdaus $^{1, a}$, Eko Budi Djatmiko ${ }^{1}$, Rudi Walujo Prastianto ${ }^{1}$, dan Muhammad Fajariansyah Ismail ${ }^{2}$ \\ ${ }^{1}$ Institut Teknologi Sepuluh Nopember, Kampus ITS Sukolilo, Sukolilo, Surabaya, Indonesia \\ ${ }^{2}$ Balai Teknologi Hidrodinamika, Jl. Hidrodinamika BPPT, Kompleks ITS, Surabaya, Indonesia \\ e-mail: afirdaus.norman.oe@gmail.com
}

Diterima : 5 Juli 2021; Direvisi: 23 Juli 2021; Disetujui: 27 Juli 2021

\begin{abstract}
Abstrak
Pemakaian floating crane barge memiliki potensi besar untuk operasi pengangkatan struktur dalam mendukung decommissioning anjungan lepas pantai pasca operasi. Respon gerak floating crane barge dalam perairan bergelombang selama operasi kelautan di laut menjadi faktor penting dalam menunjang operasional yang aman. Pada penelitian ini, respon gerak dinamis floating crane barge terhadap gelombang dilakukan dengan simulasi eksperimen di laboratorium Manoeuvring and Ocean Engineering Basin. Model uji barge yang dilengkapi dengan struktur crane boom sederhana dibuat dengan perbandingan skala 1:28. Respon gerak model uji dievaluasi dengan kondisi gelombang regular dan gelombang irregular. Karakteristik amplitudo gerak disajikan dalam grafik RAO yang mana hasilnya menunjukkan kesesuaian antara hasil eksperimen dan model linier. Respon gerak terhadap gelombang irregular mengalami peningkatan secara signifikan terjadi dari kondisi gelombang $\mathrm{Hs}=0,50 \mathrm{~m}, \mathrm{Tp}=4,00 \mathrm{~s}$ ke kondisi gelombang $\mathrm{Hs}=1,00 \mathrm{~m}, \mathrm{Tp}=5,50 \mathrm{~s}$ untuk heave sebesar 2,8 kali, untuk roll sebesar 2,5 kali dan untuk pitch sebesar 1,5 kali.
\end{abstract}

Kata kunci: eksperimen; respon gerak; floating crane; barge; gelombang

\begin{abstract}
The application of a floating crane barge has great potential for lifting operation of structure in supporting of the decommissioning of post-operational offshore platform. The motion response of a floating crane barge in waves during a marine operation of structures at sea is an important factor in carrying out of safe operations. In this study, the dynamic motion response of a floating crane barge in waves was carried out by experimental simulations in the laboratory of Manoeuvring and Ocean Engineering Basin. The barge model equipped with a structure of simple crane boom is made with a scale ratio of 1:28. The motion response of model was evaluated under both regular and irregular wave conditions. The characteristics of amplitude motion are shown in the $R A O$ graph that the results show a good match between experimental results and linear model. The motion response in random waves has increased significantly, from wave condition $\mathrm{Hs}=0,50 \mathrm{~m}, \mathrm{Tp}=4,00 \mathrm{~s}$ to wave condition $\mathrm{Hs}=1,00 \mathrm{~m}, \mathrm{Tp}=5,50 \mathrm{~s}$ for heave of 2,8 times, for roll of 2,5 times and for pitch of 1,5 times.
\end{abstract}

Keywords: experimental; motion response; barge; wave 
Analisis Respon Gerak Floating Crane Barge for the Decommissioning Struktur Lepas Pantai (Nurman Firdaus, Eko Budi Djatmiko, Rudi Walujo Prastianto, dan Muhammad Fajariansyah Ismail)

\section{PENDAHULUAN}

Produksi minyak dan gas yang berada di wilayah kerja blok migas Indonesia mengalami penurunan dari tahun ke tahun. Menurut data (Budiartha, 2018) jumlah sumur yang dibor terdiri dari 15.277 sumur aktif, 21.225 sumur aktif dan 377 kategori sumur gagal. Teknologi eksplorasi dan eksploitasi minyak dan gas yang berada di laut menggunakan fixed offshore platform berjumlah 630 unit, dengan 102 unit anjungan lepas pantai sudah tidak beroperasi dan 6 unit abandonment. Maka, stuktur lepas pantai yang umur pemakaiannya habis dan tidak menimbulkan ekonomi perlu dilakukan decommissioning (Mokhtar, 2014). Hal ini dikarenakan, fixed offshore platform yang tidak beroperasi dapat mengganggu jalur pelayaran nasional maupun internasional. Dengan adanya Peraturan Pemerintah No. 17 tahun 1974 menyatakan infrastruktur pertambangan harus dibongkar atau dimanfaatkan untuk fungsi lain (Presiden Republik Indonesia, 1974). Struktur lepas pantai yang dilakukan decommissioning perlu direncanakan dengan skema berkelanjutan dan menguntungkan (Zawawi, et al., 2012).

Mempertimbangkan potensi besar dalam industri marine operation dalam proses decommissioning diperlukan wahana teknologi transportasi sebagai solusi kegiatan pasca operasi anjungan lepas pantai di Indonesia. Sehingga, penerapan floating crane menjadi solusi alternatif yang efektif dan efisien dalam operasi pengangkatan struktur lepas pantai yang telah habis umurnya. Teknologi offshore support vessel crane (OSVC) dapat digunakan secara luas untuk mengangkat dan menurunkan peralatan struktur lepas pantai di laut (Jeong, et al., 2016). Wahana floating crane menjadi teknologi yang lebih fleksibel dan lebih cepat dalam relokasi struktur lepas pantai untuk operasi kelautan di laut sedang dan dalam (Sun, et al., 2012; Tian, et al., 2018; Zhao, et al., 2019).

Bentuk lambung crane vessel yang mudah ditemukan di lapangan dan banyak digunakan dalam operasi pengangkatan yaitu floating crane barge. Stabilitas struktur floating crane barge selama operasi pengangkatan menjadi perhatian penting dalam operasionalnya. Dalam melaksanakan penugasan decommissioning, proses pembongkaran dan pemuatan struktur akan menghadapi kondisi lingkungan bergelombang. Kondisi tinggi gelombang yang kecil dapat berpengaruh signifikan dalam respon gerak floating crane barge, sebagaimana dapat menginduksi gerak dinamis muatan dan kembali lagi mempengaruhi gerakan kapal (Nam, et al., 2015). Oleh karena itu, kajian respon gerak floating crane barge dalam lingkungan laut bergelombang penting diketahui untuk menjamin keselamatan dan keamanan selama menjalankan marine operation. Kondisi batas operasional crane vessell dalam instalasi struktur lepas pantai tergantung dari kondisi gelombang dan gerak kapal (Clauss \& Riekert, 1990).

Beberapa penelitian terbaru yang berkaitan dengan crane vessell dilakukan oleh (Chu, et al., 2021), respon gerak dinamis nonlinier kapal floating crane terhadap gelombang dengan metode simulasi numerik domain waktu. Untuk memperkirakan kinerja gerak crane vessel, variasi sea state diberikan dalam analisis penelitian seperti yang dilakukan oleh (Chen, et al., 2018; Yang, et al., 2019). Dalam kode (Det Norske Veritas, 2014), operasi pengangkatan stuktur dalam laut bergelombang oleh crane vessel dilakukan tidak lebih dari tinggi gelombang signifikan sebesar 2,0 m, sehingga kegiatan decommissioning offshore structure dilakukan pada kondisi sea state yang relatif kecil. Floating crane yang memiliki amplitudo besar dalam gelombang besar dan gerakan besar tersebut dapat menyebabkan respon gerak besar juga pada struktur terangkat (Cha, et al., 2010).

Dalam tulisan ini dilakukan kajian perilaku gerak floating crane barge terhadap variasi parameter gelombang irregular dan regular yang dilakukan dengan simulasi eksperimen di laboratorium. Selain itu, gerak amplitudo dilakukan perhitungan model matematis. Hal ini bertujuan mengetahui karakteristik gerak kapal sebagai tahap awal dalam memperkirakan kinerja olah gerak crane vessel guna mendukung kegiatan decommissioning pada kondisi lingkungan bergelombang. Pada tahap awal dalam studi ini 
dilakukan tanpa menggunakan parameter beban struktur yang diangkat oleh crane.

\section{DASAR TEORI}

\section{Spektrum Gelombang}

Besaran energi gelombang permukaan laut dapat digambarkan dengan spektrum gelombang. Spektrum gelombang yaitu fungsi kerapatan spektral daya dari displacement permukaan laut secara vertikal. Persamaan spektrum gelombang yang digunakan dalam desain struktur lepas pantai ditentukan dengan kondisi gelombang kenyataan dari lokasi perairan yang ditinjau. Pemilihan model spektrum dapat dilakukan berdasarkan kesamaan fenomena fisik gelombang di lapangan. Model spektrum gelombang yang sering digunakan di Indonesia yaitu spektrum Jonswap meskipun formula spektrum ini dikembangkan di North Sea. Ini dikarenakan terdapat kecocokan untuk perairan kepulauan seperti Indonesia (Djatmiko, 2012). Sehingga, model spektrum ini digunakan untuk membangkitkan parameter gelombang pada uji model seperti pada persamaan (1) dan (2) (Olagnon, et al., 2013),

$$
\begin{aligned}
& S_{J}=\alpha \frac{g^{2}}{(2 \pi)^{5}} \omega^{-5} \exp \left[-\frac{5}{4}\left(\frac{\omega}{\omega_{p}}\right)^{-4}\right]^{\exp \left(\frac{\left(1-\frac{\omega}{\omega_{p}}\right)^{2}}{2 \sigma^{2}}\right)} \\
& \alpha=0.076\left(\frac{U_{10}^{2}}{F g}\right)^{0.22} \\
& g=\text { percepatan gravitasi }(1)
\end{aligned}
$$

$\omega=$ frekuensi gelombang $(\mathrm{rad} / \mathrm{s}), \omega_{p}=$ frekuensi puncak spektrum gelombang ( $\mathrm{rad} / \mathrm{s}), \quad \gamma=$ faktor ketinggian (peak enhancement factor), dengan nilai berkisar 2 2,5 untuk perairan Indonesia, $\sigma=$ parameter bentuk (spectral width parameters), $\sigma=0,07$ untuk $\omega \leq \omega_{p}$ dan $\sigma=0,09$ untuk $\omega \geq \omega_{p}, U_{10}=$ kecepatan angin pada ketinggian $10 \mathrm{~m}$ di atas permukaan laut $(\mathrm{m} / \mathrm{s})$ dan $F=$ panjang bentangan angin berhembus (fetch length) (m).

\section{Respon Gerak Bangunan Apung}

Respon gerak struktur bangunan apung di dalam fluida air memiliki 6 mode gerakan bebas atau degrees of freedom (dof). Gerakan struktur apung yang diakibatkan oleh gaya eksitasi disebut gerakan translasi yang terdiri dari mode gerak surge, sway dan heave. Sebaliknya, gerakan struktur apung akibat momen eksitasi disebut gerakan rotasi yang terjadi pada titik pusat gravitasi yang terdiri dari mode gerak roll, pitch dan yaw. Semua 6 mode gerakan struktur apung terjadi pada sistem koordinat struktur pada masing-masing sumbu $\mathrm{x}, \mathrm{y}$, dan $\mathrm{z}$ yang dapat dilihat pada Gambar 1.

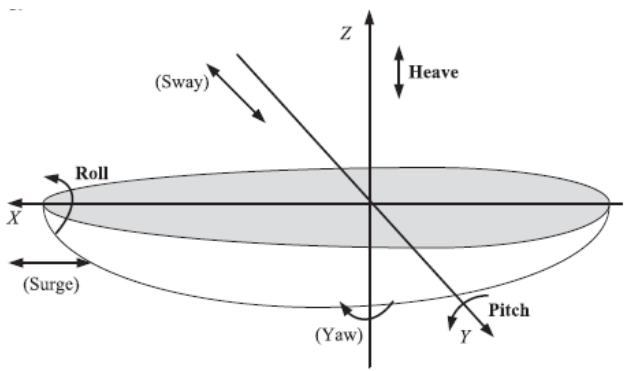

Gambar 1. Gerakan 6 dof struktur bangunan apung (Hong \& Ngo, 2012)

Struktur bangunan apung lepas pantai memiliki karakteristik gerak yang berbeda pada setiap bentuk yang berbeda pada kondisi sea state yang sama. Gerakan bangunan apung terhadap sea state memerlukan fungsi transfer setiap komponen frekuensi beban gelombang regular yang digunakan untuk menjelaskan respon gerak bangunan tersebut. Fungsi transfer dari respon bangunan apung disebut Respon Amplitudo Operator (RAO). RAO adalah rasio amplitudo gerakan bangunan terhadap amplitudo gelombang pada frekuensi tertentu. Nilai RAO dapat digunakan untuk mewakili informasi pertama terkait respon amplitudo gerak sesuai dengan frekuensi gelombang datang dengan arah yang berbeda (Gaeta, et al., 2020). Nilai RAO dalam gelombang regular dapat dihitung dengan persamaan (3).

$$
\begin{aligned}
R A O & =\frac{\zeta_{a}}{\zeta_{a}} \\
\varsigma_{a} & =\text { amplitudo gerakan bangunan apung, }
\end{aligned}
$$
untuk translasi dalam satuan (m) dan rotasi dalam 
Analisis Respon Gerak Floating Crane Barge for the Decommissioning Struktur Lepas Pantai (Nurman Firdaus, Eko Budi Djatmiko, Rudi Walujo Prastianto, dan Muhammad Fajariansyah Ismail)

satuan (deg) dan $\zeta_{a}=$ amplitudo gelombang (m).

Dalam perhitungan numerik maupun eksperimen, RAO yang diperoleh dapat digunakan untuk prediksi respon gerak bangunan apung dalam gelombang irregular dengan metode spektral analisis (Jiao, et al., 2019). Spektral respon gerak bangunan apung dapat dihitung dengan mentransformasikan respon amplitudo gerak pada gelombang regular dengan nilai energi spektrum gelombang pada lokasi perairan struktur bangunan apung beroperasi. Spektra respon gerak dalam analisis domain frekuensi dapat diperkirakan dengan persamaan (4).

$$
S_{\zeta r}(\omega)=R A O^{2} \cdot S_{\zeta}(\omega)=\left[\frac{\zeta_{a}}{\zeta_{a}}\right]^{2} \cdot S_{\zeta}(\omega)
$$

$S_{\zeta r}(\omega)=$ spektra respon gerakan bangunan apung (spectral density), untuk translasi dalam satuan $\left(\mathrm{m}^{2} . \mathrm{s} / \mathrm{rad}\right)$ dan rotasi dalam satuan $\left(\mathrm{deg}^{2} . \mathrm{s} / \mathrm{rad}\right)$ dan $S_{\zeta}(\omega)=$ spektrum gelombang (spectral density) dalam satuan $\left(\mathrm{m}^{2} . \mathrm{s} / \mathrm{rad}\right)$.

Dalam studi ini, spektra respon gerak floating crane barge terhadap gelombang irregular telah diperoleh dari hasil pengukuran eksperimen. Jika spektra respon sudah dihitung berdasarkan metode domain waktu hasil pengujian model, maka RAO bangunan apung dari kondisi gelombang irregular dapat dicari dengan subtitusi hubungan parameter yang terdapat pada persamaan (5).

$$
R A O(\omega)=\sqrt{\frac{S_{\zeta r}(\omega)}{S_{\zeta}(\omega)}}
$$

\section{METODE PENELITIAN}

\section{Model Uji Eksperimen}

Dalam studi ini, model uji floating crane barge dilakukan eksperimen di laboratorium kolam dalam Manoeuvring and Ocean Engineering Basin (MOB) dengan dimensi kolam panjang, lebar dan kedalaman 60 x 35 x 2,5 meter di Balai Teknologi Hidrodinamika, BPPT. Generator gelombang dapat membangkitkan tinggi gelombang regular dan irregular baik gelombang panjang maupun pendek.
Model uji floating barge dibuat dari material kayu lapis dengan laminasi fiberglass, dengan perbandingan skala 1:28 dari ukuran kapal full scale. Sedangkan model struktur crane dibuat bentuk secara sederhana dari konstruksi besi siku yang dirangkai dengan mur dan baut serta dibuat penguat dari sling stainless-steel.

Model struktur crane ditempatkan di dalam geladak di antara midship kapal dengan bagian haluan kapal dengan sudut luffing crane tetap sebesar $60 \mathrm{deg}$. Struktur crane bisa bergerak horisontal dengan diputar (slewing angle) secara manual, tetapi dalam studi ini posisi crane boom dilakukan pengaturan posisi fixed ke arah depan kapal. Pada sudut luffing crane 60 deg memiliki kapasitas angkat mendekati maksimum operasional crane, dan struktur crane menghadap ke arah depan umumnya dilakukan saat operasi pengangkatan seperti studi eksperimen crane vessel yang dilakukan oleh (Clauss \& Vannahme, 1999). Rancang bangun model uji secara lengkap ditunjukkan dalam Gambar 2. Tabel 1 menunjukkan dimensi utama floating crane barge beserta titik pusat gravitasi. Dalam studi ini, kondisi muatan model uji dalam kondisi ballast.

Tabel 1. Dimensi utama floating crane barge

\begin{tabular}{lcc}
\hline \multicolumn{1}{c}{ Parameter } & Full Scale & Model \\
\hline Panjang kapal (m) & 84,000 & 3,000 \\
Lebar (m) & 21,000 & 0,750 \\
Tinggi (m) & 6,160 & 0,220 \\
Sarat (m) & 2,400 & 0,107 \\
Berat crane barge (kg) & $3.468,358$ & 154,144 \\
VCG dari baseline (m) & 3,736 & 0,133 \\
LCG dari AP (m) & 41,989 & 1,499 \\
\hline
\end{tabular}

\section{Kondisi Eksperimen}

Sebelum dilakukan pengujian model uji floating crane barge di kolam MOB, jari-jari girasi memanjang (kyy) model dihitung di atas meja ukur osilasi. Dalam pengukuran ini, distribusi berat diatur sesuai dengan nilai VCG dan $L C G$ yang telah 


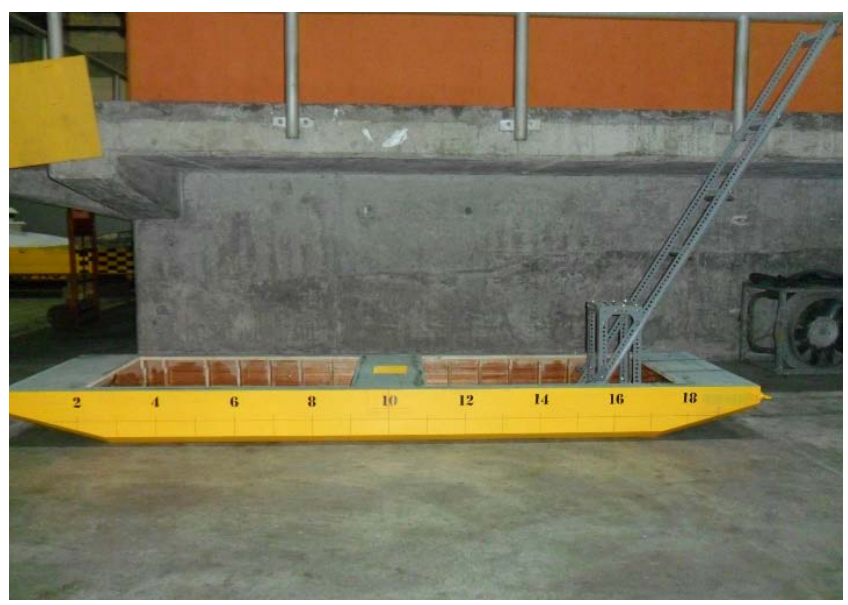

Gambar 2. Model uji floating crane barge
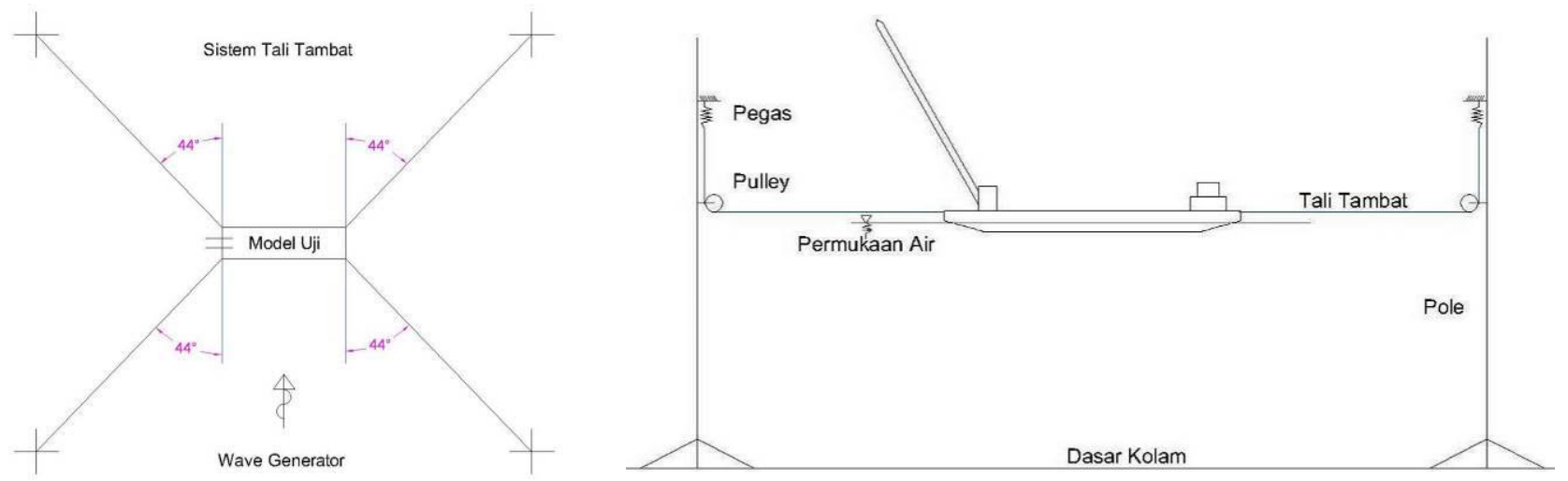

Gambar 3. Konfigurasi sistem tambat tampak atas (kiri) dan tampak samping (kanan)

direncanakan seperti yang ditunjukkan pada Tabel 1 . Metode inclining test digunakan untuk mengukur nilai tinggi metasentris melintang $\left(G M_{T}\right)$ pada kondisi aktual model uji dan periode alami gerak juga dilakukan dengan free decay test di kolam air tenang.

Tabel 2. Kondisi gelombang irregular

\begin{tabular}{llcc}
\hline Kode gelombang & Heading & $\mathrm{Tp}(\mathrm{s})$ & $\mathrm{Hs}(\mathrm{m})$ \\
\hline IRREG1 & Beam sea & 4.00 & 0.50 \\
IRREG2 & Beam sea & 5.50 & 1.00 \\
IRREG3 & Beam sea & 7.00 & 1.50 \\
IRREG4 & Beam sea & 8.50 & 2.00 \\
\hline
\end{tabular}

Dalam tulisan ini, gerakan floating crane barge hanya dipengaruhi oleh beban gelombang arah beam sea dan tanpa dipengaruhi gerakan muatan, serta tanpa memperhitungkan perubahan titik berat pada saat crane mengangkat muatan. Pemilihan gelombang beam sea dikarenakan gelombang memberikan gaya eksitasi dan momen eksitasi yang lebih besar pada gerak heave dan roll dari pada heading lainnya. Meskipun respon gerak model uji dilakukan tanpa muatan, karakteristik respon gerak kondisi awal dapat diketahui dan dievaluasi dalam rangka peningkatan kinerja olah gerak kapal di lingkungan bergelombang.

Tabel 3. Kondisi gelombang regular

\begin{tabular}{lcccc}
\hline Kode gelombang & Heading & $\begin{array}{c}\omega \\
(\mathrm{rad} / \mathrm{s})\end{array}$ & $\mathrm{T}(\mathrm{s})$ & $\mathrm{H}(\mathrm{m})$ \\
\hline REG1 & Beam sea & 1.794 & 3.50 & 1.00 \\
REG2 & Beam sea & 1.570 & 4.00 & 1.00 \\
REG3 & Beam sea & 1.256 & 5.00 & 1.00 \\
REG4 & Beam sea & 1.142 & 5.50 & 1.00 \\
REG5 & Beam sea & 0.897 & 7.00 & 1.00 \\
REG6 & Beam sea & 0.739 & 8.50 & 1.00 \\
REG7 & Beam sea & 0.661 & 9.50 & 1.00 \\
\hline
\end{tabular}


Analisis Respon Gerak Floating Crane Barge for the Decommissioning Struktur Lepas Pantai (Nurman Firdaus, Eko Budi Djatmiko, Rudi Walujo Prastianto, dan Muhammad Fajariansyah Ismail)
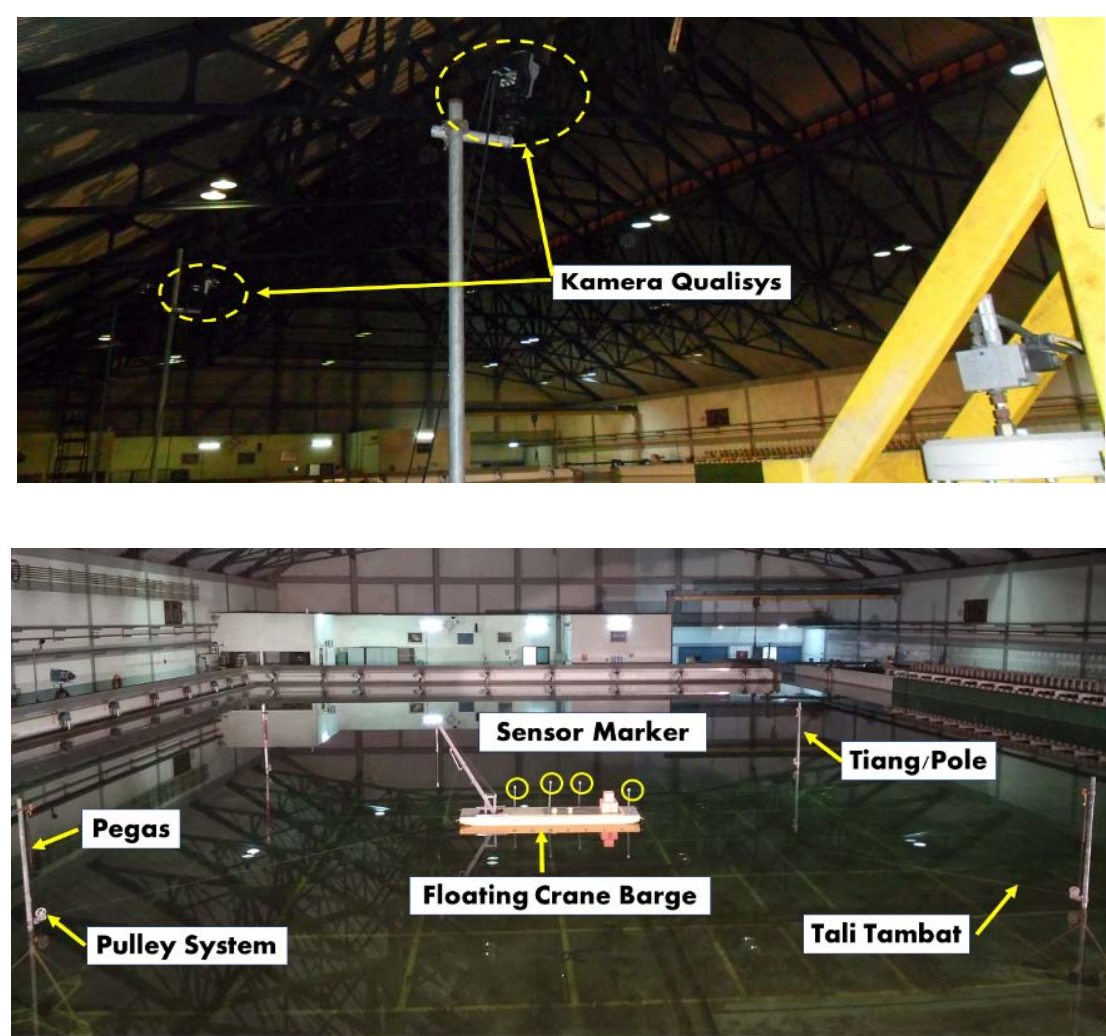

Gambar 4. Kamera Qualisys (atas) dan pengaturan model uji eksperimen di kolam (bawah)
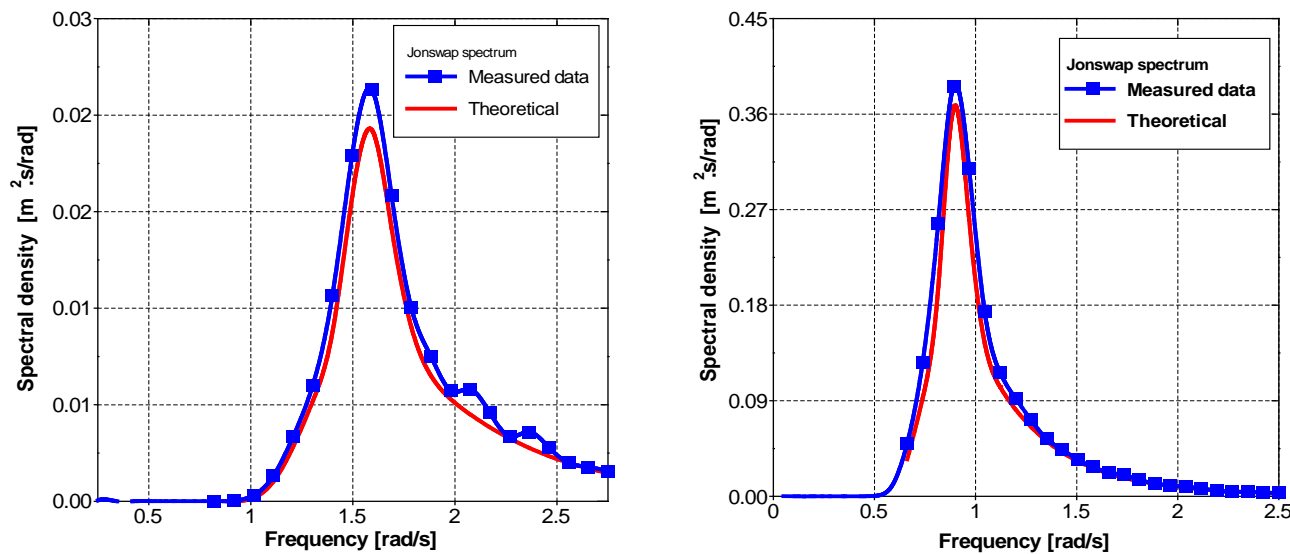

Gambar 5. Kalibrasi spektrum gelombang untuk kode IRREG1 (kiri) dan IRREG3 (kanan)

Respon gerak floating crane barge diberikan variasi parameter gelombang sesuai operasional proses decommissioning di lapangan. Selain itu, untuk memverifikasi karakteristik gerak RAO yang diperoleh dari gelombang regular dilakukan juga pembebanan gelombang irregular dalam eksperimen studi ini. Tabel 2 dan Tabel 3 menunjukkan ringkasan gelombang regular dan irregular. Tinggi dan periode gelombang yang dibangkitkan di kolam uji perlu dilakukan kalibrasi spektrum gelombang. Spektrum Jonswap digunakan dalam eksperimen studi ini, dan Gambar 5 mempresentasikan hasil kalibrasi gelombang antara spektrum gelombang data pengukuran dan teoritis. Menurut ITTC 7.5-02-07-01.2 tentang Laboratory Modelling of Waves menyatakan bahwa tolerasi perbedaan pengukuran dan teori kurang dari 5\% (ITTC, 2017).

Pada simulasi eksperimen di kolam, model uji dilakukan sistem tambat dengan konfigurasi spread mooring dengan 4 tali yang dapat dilihat dalam Gambar 3, hal ini untuk mencegah drift motion berlebih akibat gelombang pendek. Tali tambat dihubungkan dari fairlead yang terdapat di masing-masing ujung pojok geladak kapal dan 
dihubungkan dengan kondisi taut horisontal menuju pulley system yang telah dipasang pegas dengan kekakuan linier yang grafiknya dapat dilihat pada Gambar 6. Panjang tali tambat sekitar 2,2 kali dari panjang model uji floating crane barge.

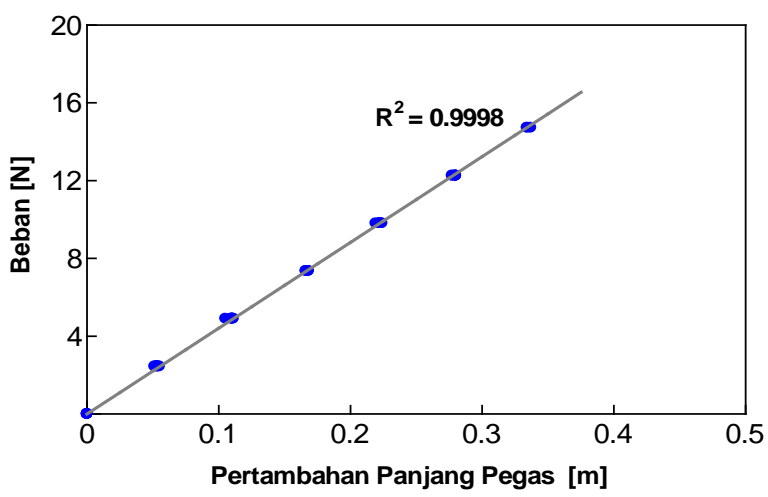

Gambar 6. Grafik Pembebanan pada Pegas

Gerak 6 dof floating crane barge diukur dengan alat kamera Qualisys yang berfungsi untuk merekam tracking gerakan rigid body pada 4 bola sensor marker yang terpasang di atas geladak model uji seperti yang ditunjukkan pada Gambar 4. Rigid body pada sensor marker ditransformasi ke titik pusat gerakan kapal yaitu titik CoG (Center of Gravity). Simulasi pengujian seakeeping dengan gelombang irregular dilakukan dengan durasi kurang dari 12 menit, sebagaimana waktu setara dengan 63 menit kondisi full scale. Sedangkan simulasi respon gerak untuk gelombang regular dilakukan dengan durasi jumlah 15-20 cycle atau osilasi gelombang.

\section{Model Matematis}

Dalam studi ini, persamaan gerak diferensial linier diturunkan berdasarkan asumsi gerakan ekskursi kapal kecil, gerakan harmonik dan gelombang sinusoidal. Persamaan gerak 6 dof struktur bangunan apung dalam analisis metode ranah frekuensi dapat ditulis sederhana seperti pada persamaan (6).

$$
(M+A(\omega)) \cdot \ddot{x}+B(\omega) \cdot \dot{x}+\left(C_{h}+C_{m}\right) \cdot x=F_{W}
$$

$M=$ matriks massa struktur kapal (kg), $A(\omega)=$ matriks massa tambah struktur kapal terhadap frekuensi $(\mathrm{kg}), B(\omega)=$ matriks damping struktur kapal terhadap frekuensi (kg.m), $C_{h}=$ matriks kekakuan gaya restoring/ hidrostatik kapal $(\mathrm{N} / \mathrm{m}), C_{m}=$ matriks kekakuan gaya tali tambat $(\mathrm{N} / \mathrm{m}), F_{W}=$ matriks gaya eksitasi gelombang $(\mathrm{N})$.

Untuk mendapatkan nilai fungsi transfer atau RAO dari persamaan gerak analisis ranah/domain frekuensi model matematis, berikut fungsi transfer dapat dihitung dengan persamaan (7) dan (8).

$$
\begin{aligned}
& \hat{\zeta}_{a}=\frac{\hat{F}_{W}}{\left(-\omega^{2}(M+A)+\left(C_{h}+C_{m}\right)+i \omega B\right)} \\
& \frac{\zeta_{a}}{\zeta_{a}}=\sqrt{\operatorname{Re}\left\{\hat{\zeta}_{a}\right\}^{2}+\operatorname{Im}\left\{\hat{\zeta}_{a}\right\}^{2}}
\end{aligned}
$$

$\hat{\varsigma}_{a}=$ matriks amplitudo respon gerak (-), $\hat{F}_{W}=$ matriks amplitudo gaya/momen eksitasi yang menyebabkan gerakan (-), $i=$ fungsi bilangan kompleks (-), $\operatorname{Re}=$ bentuk komponen riil (-) dan Im $=$ bentuk komponen imajiner (-).

\section{HASIL DAN PEMBAHASAN}

Dalam studi ini, pengujian seakeeping digunakan untuk mengetahui kinerja awal olah gerak floating crane barge terhadap beban gelombang dalam mendukung marine operation untuk kegiatan decommissioning. Kondisi lingkungan laut yang bekerja hanya beban gelombang dan parameter kondisi lingkungan lain diasumsikan diabaikan dalam penyajian tulisan ini. Dengan mempertimbangkan skala model, kedalaman air maksimum kolam setara 70 m dari permukaan laut pada kondisi kenyataan. Dalam simulasi pengujian gelombang irregular, hasil yang diperoleh berupa data time series respon gerak 6 dof. Analisis data respon gerak berdasarkan domain waktu dikonversi ke spektra gerak dengan metode analisis FFT (Fast Fourier Tranform). Setelah itu data ditransformasi ke dalam bentuk RAO menggunakan Persamaan (5). Untuk simulasi gelombang regular, RAO dihitung menggunakan persamaan (3). Untuk mengetahui perbandingan besaran respon gerak bangunan apung berdasarkan variasi gelombang regular dihitung juga significant 
Analisis Respon Gerak Floating Crane Barge for the Decommissioning Struktur Lepas Pantai (Nurman Firdaus, Eko Budi Djatmiko, Rudi Walujo Prastianto, dan Muhammad Fajariansyah Ismail)
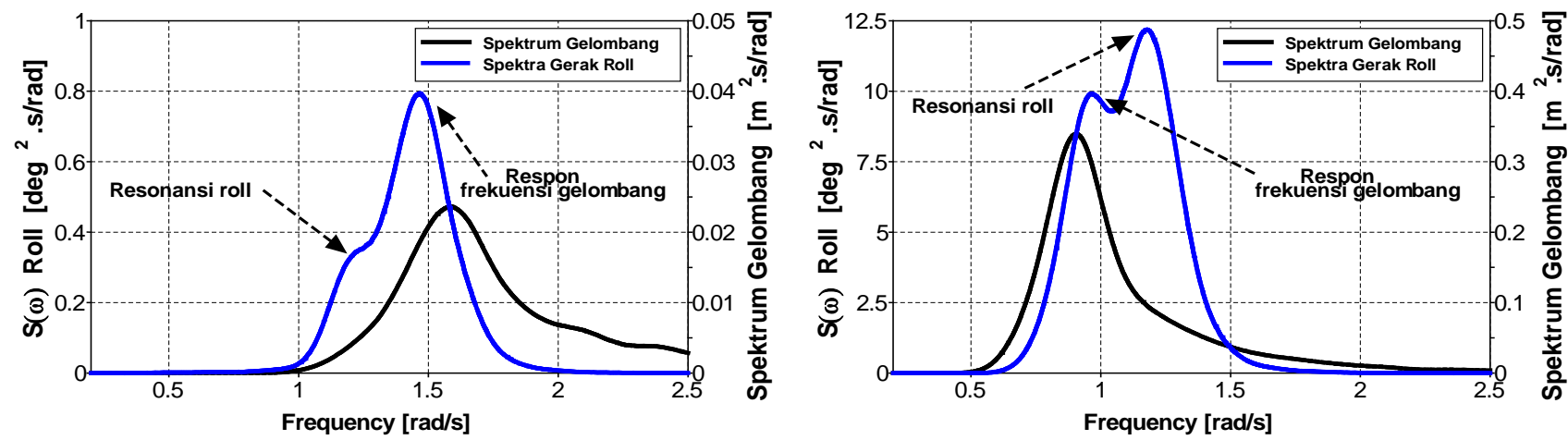

Gambar 7. Spektra respon gerak roll untuk IRREG1 (kiri) dan IRREG3 (kanan)

single amplitude pada gerakan 6 dof.

Sebagai verifikasi hasil karakteristik gerak amplitudo dalam analisis domain frekuensi, hasil RAO diplot dalam grafik yang sama antara hasil simulasi pembebanan gelombang irregular, gelombang regular serta prediksi model linier berdasarkan perhitungan model matematis dengan persamaan (8). Gambar 4 menunjukkan kondisi simulasi eksperimen model uji floating crane barge yang tertambat di kolam MOB saat pengujian seakeeping berlangsung.

Gambar 7 pada kondisi IRREG1 dan IRREG3 menunjukkan spektra respon gerak roll pada floating crane barge dengan kondisi beban gelombang irregular. Dalam hal ini, kurva spektrum gelombang diplot bersama dengan spektra gerak roll untuk mempermudah pemahaman pengaruh respon gelombang terhadap gerakan floating crane barge. Pada parameter gelombang yang relatif sangat kecil, puncak spektra gerak roll lebih dominan dipengaruhi respon frekuensi gelombang sekitar 1,48 rad/s, dari pada frekuensi alami gerak itu sendiri sekitar 1,21 rad/s. Tetapi untuk energi gelombang yang relatif lebih besar, puncak spektra repon akan menunjukkan pengaruh resonasi frekuensi roll lebih besar dari pada pengaruh respon gelombang. Dalam operasional floating crane barge pada aktivitas marine operation, respon gerak roll kapal menjadi perhatian utama khususnya dalam proses decommissioning maupun instalasi pada kondisi lingkungan laut yang bergelombang. Gerak roll pada kapal heavy-lift dan pengaruh gerak kopel dengan gerakan dinamis muatan menjadi bagian penting dalam operasi pengangkatan (Hatecke, et al., 2014).

Pengaruh propagasi gelombang arah samping tegak lurus memanjang kapal dengan kondisi zero speed dengan sistem tertambat, respon gerak bangunan apung lebih dominan ditunjukkan dalam respon gerak roll, heave, sway, dan yaw. Hal ini dikarenakan gaya dan momen eksitasi yang dihasilkan dari beban gelombang sangat besar di antara heading gelombang lainnya. Maka dari itu, pembahasan RAO diawali dengan 4 gerakan tersebut dan dilanjutkan dengan gerak surge dan pitch.

Pada kurva RAO untuk respon gerak dari gelombang irregular ditampilkan karakteristik gerak 2 variasi gelombang. Untuk variasi kode gelombang IRREG2 digambarkan dengan garis putus-putus (- -) warna biru, Sedangkan untuk IIREG4 ditunjukkan garis putus-putus warna hijau (--), dan untuk RAO geombang regular dipresentasikan dengan simbol lingkaran solid warna jingga ( ${ }^{\circ}$ ). Dan RAO model linier dipresentasikan dengan garis utuh warna merah $(-)$.

\section{RAO Gerak Roll}

Perbandingan karakteristik gerak roll floating crane barge dijelaskan pada Gambar 8, dari kurva RAO menunjukkan trend yang sesuai antara uji gelombang regular, irregular dan model linier. Puncak amplitudo tertinggi pada frekuensi sekitar $1,21 \mathrm{rad} / \mathrm{s}$ memberikan resonansi roll gerak floating 
crane barge itu sendiri. Nilai frekuensi alami gerak roll sesuai dengan hasil free decay test yang telah dilakukan di kolam air tenang sebelum diberi beban gelombang. Pada titik itu, gerak roll maksimum floating crane barge sekitar 12 deg per unit amplitudo gelombang.

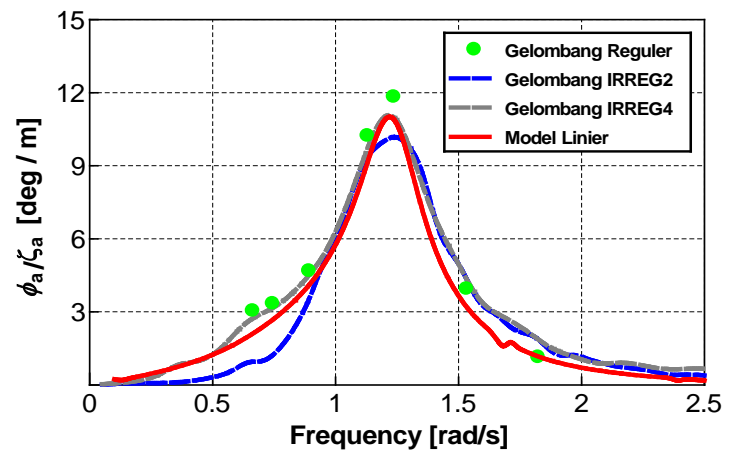

Gambar 8. RAO roll pada floating crane barge

Karakteristik gerak roll untuk gelombang IRREG4 memiliki puncak resonansi tampak agak lebih besar dari pada gelombang IRREG2, sebesar $1.2(\mathrm{deg} / \mathrm{m})$. Hal ini dikarenakan energi gelombang yang relatif besar memberikan nilai potensi damping gerak roll lebih kecil. Menurut (Journée \& Massie, 2001), pengaruh viscous pada beberapa kasus gerak rolling dapat menyebabkan koefisien damping non-linier. Koefisien damping tergantung pada frekuensi dan amplitudo osilasi gerakan. Pada gerakan vertikal bangunan apung, karakteristik gerak amplitudo pada frekuensi alami akan mengalami pembesaran jika nilai potensi damping semakin kecil.

\section{RAO Gerak Heave}

Karakteristik gerak heave yaitu gerak vertikal naik turun bangunan apung ditunjukkan dalam Gambar 9. Secara umum, trend kurva RAO untuk semua gelombang irregular, regular dan prediksi model linier memiliki kesamaan amplitudo. Secara teori, RAO gerak heave pada frekuensi rendah cenderung mendekati nilai $1(\mathrm{~m} / \mathrm{m})$ dan memiliki fase lags cenderung $0 \mathrm{deg}$. Hal ini dikarenakan, respon gerak heave pada kapal akan selalu mengikuti dari osilasi gerakan displacement vertikal gelombang akibat panjang gelombang yang besar dibanding lebar kapal. Sebagian banyak kasus, bentuk trend puncak spektra respon gerak heave akan selalu sama dengan kurva spektrum gelombang dan perbedaannya terletak pada besaran kerapatan spektral dayanya.

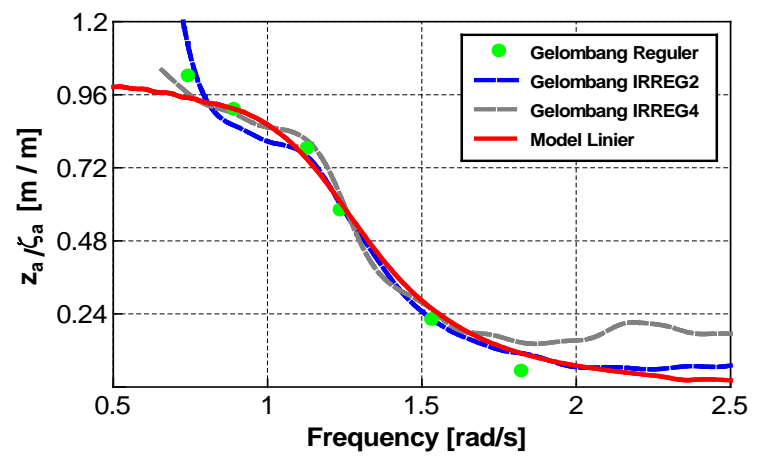

Gambar 9. RAO heave pada floating crane barge

Hasil karakteristik gerak heave pada frekuensi rendah untuk kondisi eksperimen floating crane barge tertambat menggambarkan kenaikan amplitudo lebih dari 1 meter per unit amplitudo gelombang. Hal ini dipengaruhi oleh respon tali tambat akibat kekakuan linier pegas. Kekakuan pegas pada eksperimen ini didesain dengan periode sangat tinggi untuk menghindari resonansi yang mendekati frekuensi alami gerakan vertikal sistem bangunan apung (heave, roll dan pitch). Kemudian amplitudo gerak mengalami penurunan setelah melewati frekuensi sekitar 1,05 rad/s dengan amplitudo 0,88 (m/m). Perlu diketahui, posisi frekuensi tersebut merupakan resonansi frekuensi antara gerak heave dan pitch kapal. Interaksi tersebut menyebabkan gerak kopel pada kedua gerakan tersebut. Gerak kopel terjadi dikarenakan gaya vertikal pada titik pusat gravitasi bangunan apung yang simetris dapat menyebabkan gerakan bersamaan pada heave dan pitch. Jika gerakan heave bangunan apung memiliki nilai damping lebih kecil, maka akan terjadi pembesaran respon amplitudo pada resonansi frekuensi alami dan sebaliknya. Pada frekuensi tinggi untuk gelombang IIREG4 mengalami resonansi akibat propagasi panjang gelombang pendek dibanding lebar kapal.

\section{RAO Gerak Sway}

Bentuk kurva RAO gerak horisontal menyamping terhadap sumbu y kapal atau sway 
Analisis Respon Gerak Floating Crane Barge for the Decommissioning Struktur Lepas Pantai (Nurman Firdaus, Eko Budi Djatmiko, Rudi Walujo Prastianto, dan Muhammad Fajariansyah Ismail)

memiliki kesamaan antara karakteristik gerak dari gelombang irregular maupun regular serta perhitungan model linier. Pada frekuensi lebih rendah terlihat kurva menunjukkan amplitudo gerak sangat besar, hal ini diakibatkan oleh pengaruh kekakuan pegas linier. Perlu diketahui bahwa, gerak horizontal kapal (surge, sway dan yaw) tidak memiliki nilai kekakuan hidrostatik kapal $\left(c_{11}=0\right.$, $c_{22}=0$ dan $\left.c_{66}=0\right)$. Sehingga, dalam respon gerak horisontal sistem bangunan apung dengan zero speed sangat dipengaruhi oleh respon kekakuan tali tambat.

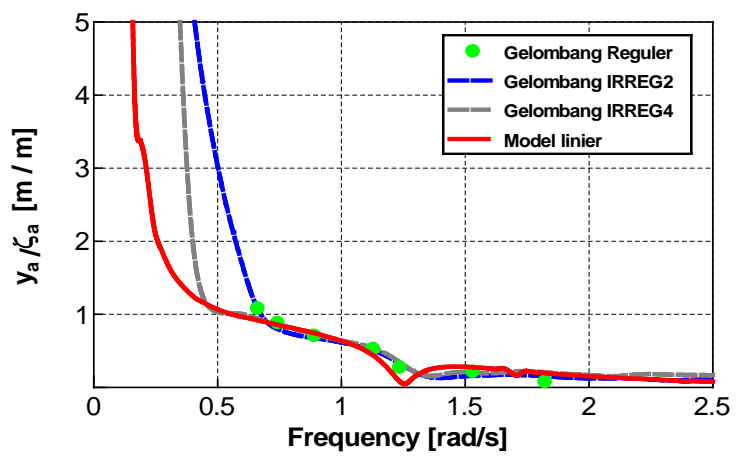

Gambar 10. RAO sway pada floating crane barge

Pada Gambar 10 menunjukkan karakteristik gerak sway pada floating crane barge terjadi penurunan amplitudo gerak pada frekuensi lebih tinggi. Penurunan amplitudo gerak agak landai setelah adanya resonansi frekuensi alami gerak roll sekitar 1,21 rad/s. Gerak sway pada floating crane barge mengalami restrained oleh tali tambat.

Gerakan drift pada gerakan horisontal pada bangunan apung yang tertambat disebabkan oleh gaya mean wave drift. Gaya ini disebabkan oleh beban gelombang second order, dengan bersama-sama sistem tambat dapat menentukan posisi keseimbangan baru pada arah tranlasi bangunan apung. Untuk amplitudo gerak frekuensi rendah pada gerakan horisontal diakibatkan oleh elemen non-linier gelombang yaitu gaya low frequency wave drift. Sedangkan amplitudo yang besar pada gerakan horisontal terjadi akibat resonansi bangunan apung tertambat yang dipengaruhi oleh eksitasi frekuensi rendah. Hal ini dapat diamati dengan jelas pada data time trace respon gerak sway dalam Gambar 11, bahwa gerak sway first order (respon frekuensi gelombang) relatif lebih kecil dibandingkan gerak pada second order (frekuensi rendah).

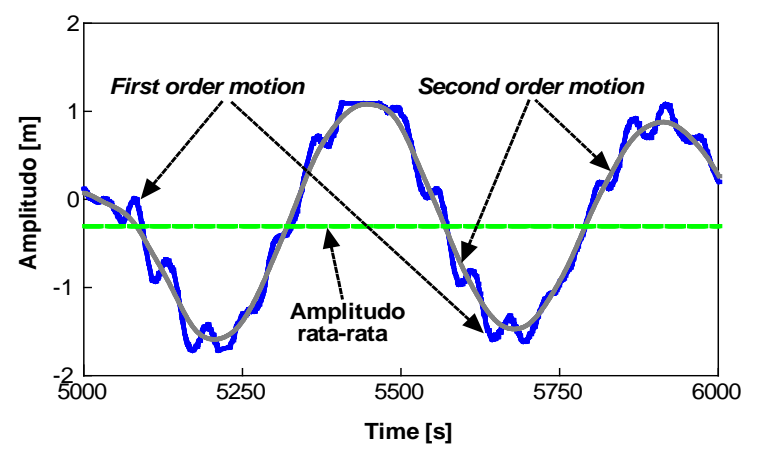

Gambar 11. Data potongan time trace respon gerak sway pada floating crane barge

\section{RAO Gerak Yaw}

RAO gerak yaw pada floating crane barge tertambat menunjukkan hasil yang sesuai antara gelombang irregular dan regular, tetapi sedikit berbeda dengan model linier. Dalam puncak kurva amplitudo gerak yaw untuk rentang frekuensi gelombang terdapat resonansi gerak roll sekitar 1,21 rad/s. Hasil resonansi ini memberikan amplitudo gerak sekitar 0,7 deg per unit amplitudo gelombang. Pada Gambar 12 menunjukkan karakteristik gerak yaw juga dipengaruhi besar oleh respon kekakuan tali tambat pada frekuensi rendah. Seperti halnya gerakan horisontal sway, amplitudo besar pada gerak yaw dipengaruhi oleh eksitasi frekuensi rendah akibat gerakan second order.

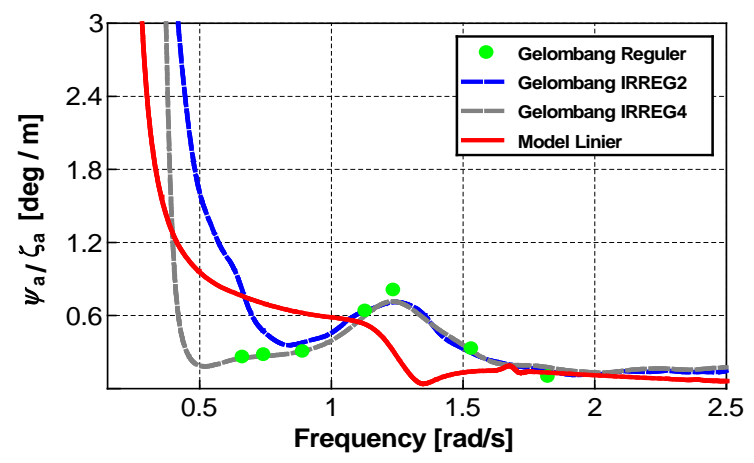

Gambar 12. RAO yaw pada floating crane barge

\section{RAO Gerak Surge}

Karakteristik gerak surge secara garis besar memiliki fenomena yang sama dengan gerak sway, hal ini dapat dilihat kurva RAO surge pada 
Gambar 13. Amplitudo gerak surge besar terjadi pada frekuensi rendah akibat eksitasi frekuensi rendah sebagaimana adanya resonansi frekuensi alami dan damping yang kecil. Frekuensi alami surge dipengaruhi besar oleh periode alami sistem tali tambat. Kurva RAO gerak surge memiliki kesamaan antara gelombang regular dan gelombang IRREG4 maupun prediksi model linier. Untuk gelombang irregular yang relatif lebih kecil terjadi sedikit perbedaan dikarenakan eksitasi gerak surge tidak dominan untuk arah gelombang beam sea.

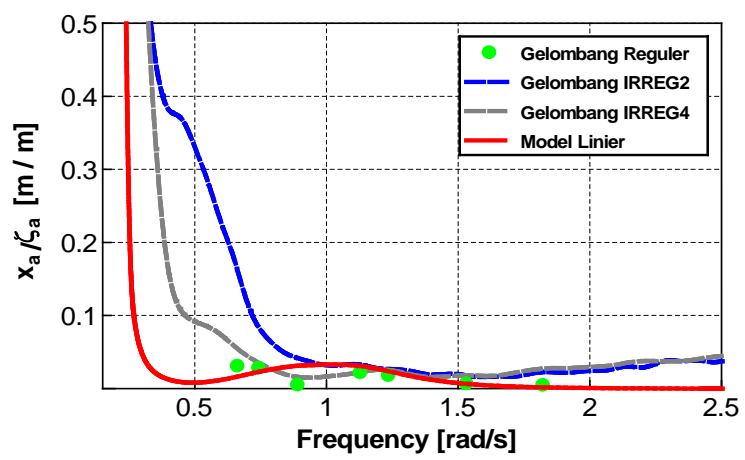

Gambar 13. RAO surge pada floating crane barge

\section{RAO Gerak Pitch}

Amplitudo gerak pitch pada gelombang irregular terjadi perbedaan antar variasi gelombang dan adanya ketidaksesuaian dengan kurva RAO gelombang regular. Hal ini dapat dipahami bahwa beban gelombang arah beam sea tidak menimbulkan momen eksitasi pitch yang signifikan dan dominan. Karakteristik RAO IRREG2 dengan model linier menunjukkan kesamaan pada puncak terbesar sekitar 1,08 $\mathrm{rad} / \mathrm{s}$ sebesar 0,3 (m/m). Untuk RAO gelombang IRREG2 menunjukkan nilai amplitudo gerak lebih besar dari pada gelombang IRREG4. Hal ini dipengaruhi oleh nilai potensi damping yang besar untuk kondisi IRREG4. Perilaku gerak pitch cenderung lebih kecil dibanding gerak rotasi lain dikarenakan memiliki kekakuan lebih besar akibat tinggi metasentris memanjang $\left(G M_{L}\right)$ yang besar akibat panjang kapal.

Pada Gambar 14 terlihat bahwa RAO gerak pitch pada gelombang IRREG2 terdapat 2 resonansi puncak amplitudo yang dominan. Puncak pertama sekitar 1,08 rad/s yang diakibatkan oleh resonansi frekuensi alami gerak pitch sendiri, dan puncak kedua sekitar 1,27 rad/s yang mendekati resonansi gerak roll. Untuk bangunan apung tertambat, gerak roll dan pitch bisa saling mempengaruhi melalui tali tambat. Setelah itu terdapat beberapa puncak resonansi kecil pada frekuensi lebih tinggi akibat gelombang pendek. Sedangkan puncak RAO kondisi gelombang IRREG4, selain dipengaruhi oleh resonansi gerakan itu sendiri juga terdapat resonansi pada frekuensi lebih rendah akibat gelombang panjang. Nilai amplitudo pitch maksimum sekitar 0,17 deg per unit amplitudo gelombang pada gelombang regular.

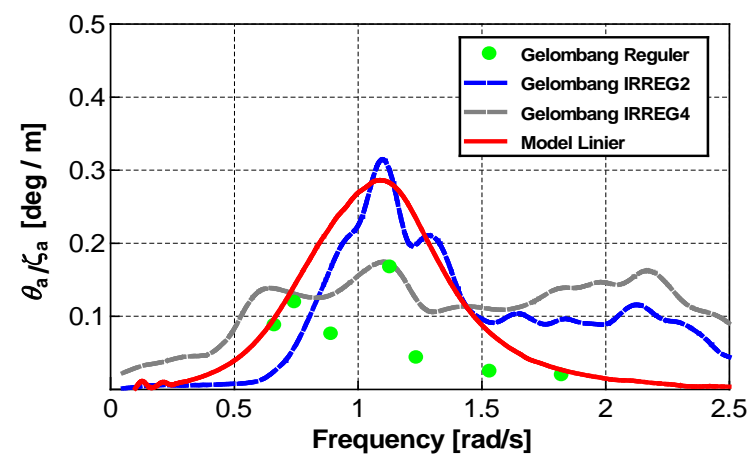

Gambar 14. RAO pitch pada floating crane barge

\section{Respon Gerak Signifikan terhadap Gelombang}

Untuk mengevaluasi kinerja respon gerak floating crane barge dalam mendukung aktivitas decommissioning struktur lepas pantai, perilaku gerak signifikan perlu diperhitungkan selama dilakukan pengujian model terhadap gelombang acak. Perhitungan respon gerak signifikan dapat menggunakan metode zero crossing period untuk data respon gerak berdasarkan domain waktu atau analisis data statistik spektra respon gerak berdasarkan domain frekuensi.

Gambar 15 menunjukkan perbandingan respon gerak significant single amplitude pada floating crane barge untuk mode gerak translasi dengan 4 perbedaan kondisi gelombang irregular. Sedangkan Gambar 16 membandingkan nilai significant single amplitude pada kapal untuk mode gerak rotasi. Dari kedua gambar tersebut, semua respon gerakan floating crane barge tertambat mengalami peningkatan dengan meningkatnya 
Analisis Respon Gerak Floating Crane Barge for the Decommissioning Struktur Lepas Pantai (Nurman Firdaus, Eko Budi Djatmiko, Rudi Walujo Prastianto, dan Muhammad Fajariansyah Ismail)

tinggi gelombang signifikan dan periode puncak gelombang. Peningkatan semua respon gerak secara ekstrim terjadi dari kondisi gelombang IRREG1 ke kondisi gelombang IRREG2. Hal ini dikarenakan periode puncak spektrum gelombang IRREG2 berdekatan dengan frekuensi alami gerak vertikal sistem floating crane barge.

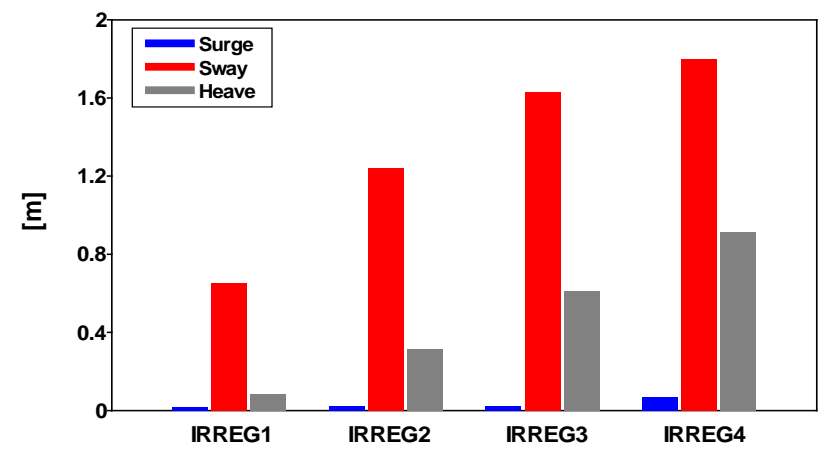

Gambar 15. Nilai significant single amplitude mode gerak translasi floating crane barge

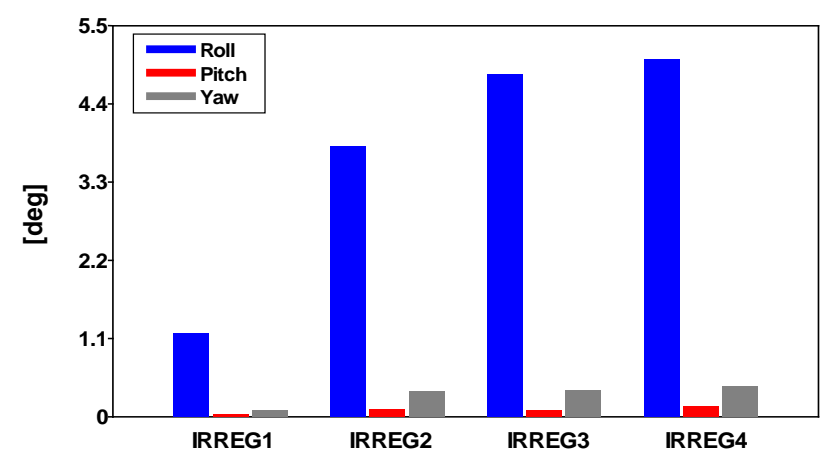

Gambar 16. Nilai significant single amplitude mode gerak rotasi floating crane barge

Kenaikan terbesar terjadi pada gerak heave sebesar 2,8 kali, sedangkan untuk gerak roll sebesar 2,3 kali dan untuk gerakan pitch kapal sebesar 1,5 kali. Setelah itu, kenaikan respon gerak kapal dari kondisi IRREG2 ke IRREG3 dan dari kondisi IRREG3 ke IRREG 4 sebesar kurang dari 1 kali. Selain pengaruh besaran tinggi gelombang signifikan, periode puncak spektrum gelombang berpengaruh besar pada respon gerak floating crane barge selama beroperasi di laut bergelombang. Seperti studi eksperimen yang dilakukan oleh (Nam, et al., 2017) tentang respon gerak floating crane vessel selama instalasi subsea manifold terhadap variasi gelombang irregular dengan kondisi tinggi gelombang signifikan tetap dan periode gelombang yang berbeda. Hasilnya menunjukkan bahwa respon gerak roll dan pitch terbesar terjadi pada periode gelombang yang berdekatan dengan frekuensi alami kedua gerakan tersebut.

Kriteria batas perilaku respon gerak floating crane barge terhadap gelombang acak selama operasi pengangkatan struktur sangat penting. Dalam studi yang dilakukan oleh (Clauss \& Riekert, 1990), kriteria batas untuk operasi crane vessel untuk significant single amplitude gerakan vertikal selama marine operation yaitu gerak roll $\leq 3^{\circ}$, untuk gerak pitch $\leq 1^{\circ}$, dan untuk gerak heave $\leq 0,6$ $\mathrm{m}$. Menurut data eksperimen dalam studi operasi pengangkatan kapal selam dengan crane kondisi arah gelombang beam sea yang dilakukan (Chen, et. al., 2020), respon gerak heave dan roll kapal saat mengangkat struktur lebih kecil dari pada kondisi kapal tanpa ada muatan struktur terangkat.

Berdasarkan hasil eksperimen respon gerak floating crane barge arah gelombang beam sea, kondisi aman dalam marine operation dilakukan pada parameter gelombang yang lebih kecil dari kondisi IRREG2. Dikarenakan respon gerak heave dan roll pada kondisi parameter gelombang yang relatif lebih besar melebihi kriteria batas operasional. Periode gelombang yang berdekatan dengan periode alami gerakan sistem kapal menjadi pertimbangan dan perhatian penting saat operasional floating crane barge di lingkungan bergelombang. Hal ini dapat meningkatkan respon gerakan kapal walaupun dengan tinggi gelombang yang relatif kecil.

\section{KESIMPULAN}

Studi ekperimen dilakukan untuk mengetahui respon gerak floating crane barge dalam kondisi bergelombang guna mendukung decommissioning struktur lepas pantai. Dari serangkaian model uji, karakteristik gerak dari gelombang irregular dan regular serta model linier menunjukkan hasil kurva RAO yang sesuai. Amplitudo gerak maksimum roll dan pitch terletak pada frekuensi alami gerak itu sendiri untuk arah gelombang beam sea. Respon gerak amplitudo pada gerakan vertikal sangat dipengaruhi oleh potensi damping system. Pada 
gerakan floating crane barge tertambat, respon gerakan horisontal sistem menimbulkan gerakan yang besar pada frekuensi lebih rendah akibat eksitasi frekuensi rendah yang dipengaruhi oleh periode alami kekakuan tali tambat dan gerakan second order.

Respon gerak signifikan pada floating crane barge terhadap gelombang acak semakin besar jika adanya peningkatan kondisi tinggi gelombang signifikan dan periode gelombang. Periode puncak spektrum gelombang yang berdekatan dengan frekuensi alami gerakan vertikal sistem dapat berkontribusi besar dalam peningkatan secara signifikan pada respon gerak bangunan apung. Sesuai kriteria batas operasional, floating crane barge dapat diterapkan untuk operasi pengangkatan struktur yang aman dalam kondisi gelombang yang relatif lebih kecil.

\section{UCAPAN TERIMA KASIH}

Penulis utama sebagai corresponding author mengucapkan terima kasih kepada Beasiswa Saintek BRIN yang telah memberikan dukungan finansial tugas belajar tahun 2019-2021. Penulis juga berterima kasih kepada Balai Teknologi Hidrodinamika - BPPT dalam kontribusi fasilitas sarana dan prasarana untuk eksperimen dilakukan di kolam uji Maneuvering and Ocean Engineering Basin (MOB).

\section{DAFTAR PUSTAKA}

Budiartha, K. (2018). Abandonment and Site Restoration, Jakarta: SKK Migas.

Cha, J. H., Roh, M. II \& Lee, K. Y. (2010). Dynamic Response Simulation of a Heavy Cargo Suspended by a Floating Crane Based on Multibody System Dynamics. Ocean Engineering, Vol. 37(14-15), pp. 1273-1291.

Chen, X., Zhu, R. C., Zhao, J., Zhou, W. J., \& Fan, J. (2018). Study on Weakly Nonlinear Motions of Ship Advancing in Waves and Influences of Steady Ship Wave. Ocean Engineering, Vol. 150, pp. 243-257.
Chen, Y., Ma, L., Duan, W., \& Liu, P. (2020). Experimental Study on Coupled Motions of Mother Ship Launching and Recovering of Human-Occupied Vehicle in Regular Waves. Journal of Marine Science and Application, Vol. 19 (1), pp. 53-63.

Chu, Y., Li, G., Hatledal, L. I., Holmeset, F. T., \& Zhang, H. (2021). Coupling of Dynamic Reaction Forces of a Heavy Load Crane and Ship Motion Responses in Waves. Ships and Offshore Structures, pp. 1-10.

Clauss, G. F. \& Riekert, T. (1990). Operational Limitations of Offshore Crane Vessels. Houston, Proceedings of the Annual Offshore Technology Conference.

Clauss, G. F., \& Vannahme, M. (1999). An Experimental Study of the Nonlinear Dynamics of Floating Cranes. Brest, International Offshore Polar Engineering Conference.

Det Norske Veritas. (2014). Recommended Practice DNV-RP-H201 for Lifting Appliances used in Subsea Operations, Bærum: DNV GL.

Djatmiko, E. B. (2012). Perilaku dan Operabilitas Bangunan Laut di Atas Gelombang Acak. Surabaya: ITS Press.

Gaeta, M. G., Segurini, G., Moreno, A. M., \& Archetti, R. (2020). Implementation and Validation of a Potential Model for a Moored Floating Cylinder Under Waves. Journal of Marine Science and Engineering, Vol. 8 (2), pp. 131-147.

Hatecke, H., Krüger, S., Christiansen, J., \& Vorhölter, H. (2014). A Fast Sea-keeping Simulation Method for Heavy-Lift Operations Based on Multi-Body System Dynamics. Proceedings of the International Conference on Offshore Mechanics and Arctic Engineering.

Hong, K. S., \& Ngo, Q. H. (2012). Dynamics of the Container Crane on a Mobile Harbor. Ocean Engineering, Vol. 53, pp. 16-24.

ITTC. (2017). ITTC - Recommended Procedure and Guidelines Laboratory Modelling of Waves: Regular, Irregular and Extreme Events.

Jeong, D. H., Roh, M. II, \& Ham, S. H. (2016). 
Analisis Respon Gerak Floating Crane Barge for the Decommissioning Struktur Lepas Pantai (Nurman Firdaus, Eko Budi Djatmiko, Rudi Walujo Prastianto, dan Muhammad Fajariansyah Ismail)

Lifting Simulation of an Offshore Supply

Vessel Considering Various Operating Conditions. Advances in Mechanical Engineering, Vol. 8 (6), pp. 1-13.

Jiao, J., Chen, C., \& Ren, H. (2019). A Comprehensive Study on Ship Motion and Load Responses in Short-Crested Irregular Waves. International Journal of Naval Architecture and Ocean Engineering, Vol. 11 (1), pp. 364-379.

Journée, J. M. J., \& Massie, W. W. (2001). Offshore Hydromechanics (First Edit). Delft: Delft University of Technology.

Mokhtar, H. K. M. (2014). Decommissioning of Offshore Platforms. Diakses pada 21 Juni 2021 dari https://docplayer.net/37906932Decommissioning-of-offshore-platforms.html.

Nam, B. W., Kim, N. W., Choi, Y. M., Hong, S. Y., \& Kim, J. W. (2015). An Experimental Study on Deepwater Crane Installation of Subsea Equipment in Waves. Kona, International Society of Offshore and Polar Engineers (ISOPE).

Nam, B. W., Kim, N. W., \& Hong, S. Y. (2017).

Experimental and Numerical Study on Coupled Motion Responses of a Floating Crane Vessel and a Lifted Subsea Manifold in Deep Water. International Journal of Naval Architecture and Ocean Engineering, Vol. 9 (5), pp. 552-567.

Olagnon, M., Ewans, K., Forristall, G., \& Prevosto, M. (2013). West Africa Swell Spectral Shapes. Proceedings of the International Conference on Offshore Mechanics and Arctic Engineering.
Presiden Republik Indonesia. (1974). Peraturan Pemerintah Republik Indonesia Nomor 17 Tahun 1974 tentang Pengawasan Pelaksanaan Eksplorasi dan Eksploitasi Minyak dan Gas di Daerah Lepas Pantai 1.

Sun, L., Eatock, T. R., \& Choo, Y. S. (2012). Multi-Body Dynamic Analysis of Float-Over Installations. Ocean Engineering, Vol. 51, pp. 1-15.

Tian, X., Wang, P., Li, X., Wu, X., Lu, W., Wu, C., Hu, Z., Rong, H., Sun, H., Wang, A., Lin, D., Fu, S., Zu, Y., Cho, C., Zhou, T., Zhang, D., \& Chen, Y. (2018). Design and Application of a Monitoring System for the Floatover Installation. Ocean Engineering, Vol. 150, pp. 194-208.

Yang, X. R., Gan, Q. M., Wang, Y. H. \& Wang, G. D. (2019). Dynamic Response Analysis of the Lifting Load System of a Crane Ship in Irregular Waves. Journal of Marine Science and Technology, Vol. 27 (6), pp. 481-497.

Zawawi, N. A. W. A., Liew, M. S. \& Na, K. L. (2012). Decommissioning of Offshore Platform: A Sustainable Framework. CHUSER 2012 - 2012 IEEE Colloquium on Humanities. Science and Engineering Research, pp. 26-31.

Zhao, Y., Cheng, Z., Gao, Z., Sandvik, P. C., \& Moan, T. (2019). Numerical Study on the Feasibility of Offshore Single Blade Installation by Floating Crane Vessels. Marine Structures, Vol. 64 (7491), pp. 442-462. 